\title{
How much does education matter and why? : the effects of education on socio-economic outcomes
}

Citation for published version (APA):

van der Velden, R. K. W., \& Wolbers, M. H. J. (2004). How much does education matter and why? : the effects of education on socio-economic outcomes. Researchcentrum voor Onderwijs en Arbeidsmarkt, Faculteit der Economische Wetenschappen. ROA Research Memoranda No. 2E https://doi.org/10.26481/umaror.200402E

Document status and date:

Published: 01/01/2004

DOI:

10.26481/umaror.200402E

Document Version:

Publisher's PDF, also known as Version of record

\section{Please check the document version of this publication:}

- A submitted manuscript is the version of the article upon submission and before peer-review. There can be important differences between the submitted version and the official published version of record.

People interested in the research are advised to contact the author for the final version of the publication, or visit the DOI to the publisher's website.

- The final author version and the galley proof are versions of the publication after peer review.

- The final published version features the final layout of the paper including the volume, issue and page numbers.

Link to publication

\footnotetext{
General rights rights.

- You may freely distribute the URL identifying the publication in the public portal. please follow below link for the End User Agreement:

www.umlib.nl/taverne-license

Take down policy

If you believe that this document breaches copyright please contact us at:

repository@maastrichtuniversity.nl

providing details and we will investigate your claim.
}

Copyright and moral rights for the publications made accessible in the public portal are retained by the authors and/or other copyright owners and it is a condition of accessing publications that users recognise and abide by the legal requirements associated with these

- Users may download and print one copy of any publication from the public portal for the purpose of private study or research.

- You may not further distribute the material or use it for any profit-making activity or commercial gain

If the publication is distributed under the terms of Article $25 \mathrm{fa}$ of the Dutch Copyright Act, indicated by the "Taverne" license above, 


\section{How much does education matter and why?}

The effects of education on socio-economic outcomes

ROA-RM-2004/2E

Rolf van der Velden, Maarten Wolbers

Research Centre for Education and the Labour Market

Faculty of Economics and Business Administration Maastricht University

Maastricht, May 2004 
ISBN 90-5321-390-2

Sec04.049 
Contents

Pages

Abstract

1 Introduction 1

2 Theoretical issues 2

3 Statistical modeling issues 3

4 Data and variables $\quad 4$

5 Results $\quad 8$

6 Conclusions 19

$\begin{array}{ll}\text { References } & 21\end{array}$

$\begin{array}{ll}\text { Appendix A } & 23\end{array}$ 



\begin{abstract}
This article explores the total (measured and unmeasured) effect of education on different socio-economic outcomes. The analysis shows that the usual regression models typically underestimate the effects of education. The effects of education are decomposed into three sources of variation: courses of study, schools and student composition. Schools do not seem to have a large impact. A significant part of the effect of education stems from differential selection of students into courses of study. However, there is a notable difference between social and economic rewards. Apart from level of education, selectivity and specificity of the course of study turn out to affect the labor market outcomes.
\end{abstract}





\section{Introduction}

This article focuses on the effects of education during the transition from school to work. Sociologists and economists have a long empirical tradition in analyzing the effects of education on e.g. occupational prestige, income and employment status (Blau and Duncan 1967; Shavit and Müller 1998; Kerckhoff, Raudenbush and Glennie 2001; Ryan 2001; Müller and Gangl 2003). Most of this research points to clear and undisputed effects of education. In spite of that, it is surprising to note that previous research never addressed the basic question: "How much does education really matter?" The results up-to-now typically reveal only a part of the effects of education, e.g. the effect of level of education, years of schooling or some combination of level and track such as in the CASMIN educational classification (see Müller, Luttinger, König and Karle 1989). However, important as these characteristics may be, they tap of only a part of the effects of education. Within a specific level, courses of study differ widely in the provision of field-related resources (Kalmijn and Van der Lippe 1997; Van de Werfhorst and Kraaykamp 2001), which in turn may affect socio-economic outcomes. However, most analyses do not systematically take into account the effects of differences in courses within a given level of education. Moreover, courses of study can be taken at different schools that in turn affect the socio-economic outcomes. Effects of this kind have been shown e.g. for the reputation of the college (Wilson and Smyth-Lovin 1983), the social network of the college (Rosenbaum, DeLuca, Miller and Roy 1999) and the quality of the school (Dolton and Vignoles 2000; Wilson 2002). Again, most analyses do not systematically take into account the effects of schools on socio-economic outcomes, and when they do, they are restricted to the measured characteristics of schools (e.g. reputation). The results of previous analyses therefore typically underestimate the effects of education. The effect of education is more than just the effect of years of schooling. It also relates to the effect of the specific course of study or the effect of the specific school that was attended. In this article, we first try to assess the total effect of education on various socio-economic outcomes, by taking account of measured as well as unmeasured characteristics of education.

The second issue, then, has to do with the interpretation of the effects of education: why does education have an effect? In general one can identify three sources of variation within education. There are differences in the content of courses of study (affecting what is being taught), differences in teaching environment or schools (affecting how things are taught) and differences in selection into courses of study (affecting who is being taught). As a result, effects of education on socio-economic outcomes can be related to differences in the student population, differences between schools and differences between courses of study. For analytic reasons, it is important to be able to differentiate between these three components of variation as they have clearly different connotations about why education has an effect.

Both questions (i.e. how much does education matter, while taking account of measured and unmeasured effects of education as well as why does it matter and the related decomposition of educational effects into the three sources of variation) can be adequately dealt 
with in random coefficient or multi level models (Bryck and Raudenbush 1992; Goldstein 1995; Snijders and Bosker 1999). In this article we use these models to:

- estimate the total effect of education on different socio-economic outcomes for schoolleavers;

- decompose this effect into effects due to differences in student composition, differences between schools and differences between courses of study.

For the purpose of the latter point we use several indicators to explain the effects of the individual variation within schools and courses of study, the variation between school-course combinations and the variation between courses of study. At the level of course characteristics, for instance, we look not only at the effects of years of schooling (level of education), but also at the variation in quality within given levels of education (the selectivity of the course) and the extent to which a course of study specifically prepares for a job (the specificity of the course).

\section{Theoretical issues}

Demonstrating that there is an empirical relationship between educational attainment and socio-economic outcomes does not necessarily mean that education actually caused these outcomes. In fact, this very question forms the heart of the dispute between various theories dealing with the allocation and selection process on the labor market (Pallas 2000; Bills 2003). According to human capital theory (Schultz 1961; Becker 1964), people acquire skills in education that make them more productive for future jobs. By investing in education, they improve their productivity for future jobs. As productivity in the job is mainly determined by the worker characteristics (i.e. his or her human capital), investment in education increases the future wages. This view has been challenged in the job competition model from Thurow (1975). This model assumes that the productivity in the job is determined by characteristics of that job rather than characteristics of the worker. It is also assumed that work related skills are mainly acquired on-the-job and not in education. Education in this view serves as a screening device or 'signal' (Spence 1973), indicating general characteristics such as learning abilities, motivation and perseverance that enable school-leavers to acquire new job skills. Whether or not these generic skills are actually developed in education is not important. What counts is that these generic skills are important predictors of the training costs, and employers will therefore use educational credentials to screen job applicants and put them in an imaginary labor queue (Thurow 1975). Credential theorists like Collins (1979), go even further, by arguing that elites use educational credentials to control the access to high-level status groups. Network theories point to yet another mechanism through which education may exert its influence. In this view, institutions of education offer their students access to relevant social networks that help them find their way on the labor market (Rosenbaum, Kariya, Settersten and Maier 1990). The so-called Jobs-Entrusted-to-School system (Jisseki-Kankei) in Japan, where jobs are offered to schools and schools allocate students to jobs (Rosenbaum and Kariya 1991) is often recalled as an example here. 
This article does not aim to settle these theoretical issues. Instead, we take the more pragmatic view that different effects of education are present at the same time. That is, on the one hand, education screens on certain characteristics that are in itself valuable on the labor market, but which are not always 'produced' in education. On the other hand, students acquire skills in education that enable them to perform well on the labor market. Next to this, education also has effects that are not directly related to the competencies that schoolleavers possess but e.g. to the resources schools offer for entering the labor market.

It will not always be easy to distinguish these theoretical effects firmly in an empirical analysis. What is important though, is to keep an open mind about the nature and background of educational effects. Is this effect due to selection of certain students with favorable characteristics (e.g. higher learning ability, social background) into different courses of study or is it related to the content of education? Moreover, we should also bear in mind that some effects of education are related with supply and demand differences on the labor market, rather than with differences in the competencies that have been acquired. Again, it will not be easy to always firmly distinguish between these two explanations: are the school-leavers from of a particular course of study less in demand because they have less competencies or because there is a (temporary) imbalance between supply and demand?

\section{Statistical modeling issues}

The statistical modeling involves three particular issues. A first problem that has to be tackled is the estimation of the total effect of education. As noted before, conventional regression analysis typically underestimates the effects of education as it only shows the impact of measured characteristics, like level of education. To assess the total effect one should take into account both measured and unmeasured effects of education. The second problem is that we would like to de-compose the total effect of education into three sources of variation: differences in the student composition, differences between schools and differences between courses of study.

To deal with this, we will use random coefficient or multi level models. The basic idea of multi level analysis is that data that have a nested structure, are not adequately represented by the probabilistic model of multiple regression analysis, but should be analyzed in a hierarchical linear model or random coefficient model (Bryck and Raudenbush 1992; Goldstein 1995; Snijders and Bosker 1999). Let $Y$ denote some socio-economic outcome, and $X$ is a vector of characteristics of individual $i, S$ is a vector with characteristics of school $S$ and $C$ is a vector with characteristics of course of study C. $R, U$ and $V$ are random error terms at the individual, school and course of study level respectively. Then the specified model is:

$Y_{\text {isc }}=a 1+a 2(X)_{i s c}+a 3(S)_{s c}+a 4(C)_{c}+R_{i s c}+U_{s c}+V_{c}$ 
This model has a hierarchical structure in which individuals are nested in school-course combinations and these are - in turn - nested in courses of study. By modeling courses of study as the highest level, we can easily assess the total variation due to systematic differences in courses of study. Note that in order to maintain the hierarchical structure, the intermediate level is defined as school-course combinations rather than schools. This also makes sense in a theoretical way. The common variance of school-leavers from a particular school is at the school-course combination rather than at the school level as such. Moreover, this gives us the opportunity to model course-specific 'effectiveness' of schools. To give an example: the quality of course $C_{1}$ might be the highest in school $S_{1}$, whereas the quality of course $\mathrm{C}_{2}$ might be the highest in school $\mathrm{S}_{2}$. If we would look at the general effectiveness of schools, this difference would not be detected.

The usual way to proceed is to start with the calculation of a so-called empty model that gives an indication of the amount of variation that can be attributed to the different levels (individuals, schools, courses of study). Note however that these results cannot directly be interpreted as effects that are due to the particular course followed or effects of the school attended. Part of the systematic variation between schools or courses of study is due to differential selection of students into schools and courses or to other factors that are unrelated to characteristics of the school or the course of study. Therefore we will proceed in the next models by adding variables that try to control as good as possible for these composition effects, allowing us to get closer to the 'true' effects of education.

One particular issue to be raised is the calculation of variance components in the case of logistic regression analyses. To calculate the explained variance in a logistic 3-level random intercept model, we followed the method proposed by Snijders and Bosker (1999: 225-227). The explained variance is calculated as the observed variance of the linear predictor $Y$ using the estimated coefficients of the model. The total variance is then calculated as the sum of this explained variance plus the residual level one, level two and level three variances and the explained variance is the ratio of explained and total variance. Note, however, that "such values are known for single-level logistic regression to be usually considerably smaller than the OLS R ${ }^{2}$ values obtained for predicting continuous outcomes" (Snijders and Bosker 1999: 226).

\section{Data and variables}

\section{Data}

For the empirical analysis we use data from the annual school-leaver surveys held by the Research Center for Education and the Labor Market (ROA). These cross-sectional surveys map the transition from school to work for school-leavers in the Netherlands approximately one year and a half after leaving education. We analyze the data from the 1998 wave, thus covering school-leavers from the school year 1996-1997. The surveys cover school-leavers with a qualification from any type of secondary and tertiary education in the Netherlands. The school-leavers receive a mail questionnaire that collects data on employment chances 
(unemployment spells, job search), the employment contract (temporary, part-time), job characteristics (wages, job level, job requirements), and employer characteristics (sector, firm size). In addition, in the 1998 wave, questions were asked about the characteristics in work that school-leavers value most.

For the analysis, we select school-leavers with a qualification from full-time intermediate vocational education (MBO: short tracks and long tracks) and graduates from higher vocational education ( $\mathrm{HBO}$ ) and universities (WO). These qualifications represent the majority of the regular outflow to the labor market. The different qualifications can be considered as successive in level (i.e. short track MBO < long track MBO < HBO < WO). Within this sample, we select those respondents who - at the moment of the survey belong to the labor force. This selection results in a sample of maximally 21,272 individuals, maximally 992 school-course combinations and 220 courses of study. The data are grouped as a three-level hierarchy with individuals nested in school-course combinations and schoolcourse combinations nested in courses of study.

\section{Dependent variables}

We analyze four different socio-economic outcomes. The first is the likelihood of being unemployed as against having a paid job. The second variable - restricted to those who have a paid job - looks at the likelihood of having a temporary job. We define permanent employment to include jobs with a contract of unlimited duration and jobs with the prospect of permanent employment. The third dependent variable is the occupational prestige of the job at the time of the survey. For this purpose, prestige scores were assigned to job titles according to a scale developed for the Netherlands by Sixma and Ultee (1984). This scale varies from 13 points (for occupations with the lowest prestige) up to and including 87 points (for occupations with the highest prestige). Finally, we analyze the natural log of the gross hourly wages as a dependent variable.

\section{Independent variables}

At the individual level, we include the following characteristics: age, gender, social background, ethnicity, level of first-phase secondary education and work values. Age is measured in years and varies between 18 and 34 . Note that all respondents left fulltime education about one year and a half before the survey was held. Age is therefore only partly related to working experience. The main reason to include this variable is to control for agerelated differences in minimum wages. Social background is indicated by the educational level of the parents, measured in average years of schooling of both parents (see appendix A). Ethnicity is a dummy variable distinguishing between ethnic minorities and natives. We follow the official definition: individuals belong to an ethnic minority if either they are born in a non-OECD country or if at least one of their parents is born in a non-OECD country. The level of first-phase secondary education indicates the highest track followed in the first phase of secondary education before entering higher education ( $\mathrm{HBO}$ and $\mathrm{WO}$ ) or intermediate vocational education (MBO). It distinguishes pre-university education (VWO), higher general secondary education (HAVO) and lower general secondary education/preparatory vocational 
education (MAVO/VBO). These tracks have differential possibilities for further education (see appendix A). However, students do not necessarily choose the highest form of further education possible. Therefore, this variable may indicate differences between students in scholastic abilities within the different courses in further education (WO, HBO and MBO). Finally, respondents have been asked about ten characteristics they may find important in work, as indicators of the individual's work motivation. Response categories range from 'not important at all' to 'very important' (on a five-point scale). Factor analysis indicates three underlying dimensions: intrinsic work values (with the items 'autonomy', 'work variety', 'responsibility', 'creativity' and 'challenge'), extrinsic work values (with the items 'high income' and 'permanent job') and social work values (with the items 'possibility to combine work and family', 'contacts with colleagues' and 'doing something useful for the community'). The three dimensions explain a total of 55 percent of the total variation and are reasonably reliable, given the small number of items involved per dimension (with a Cronbach's alpha of $0.75,0.46$ and 0.51 respectively).

At the school-course combination level, we include the average parental level of education. This variable can indicate two kinds of effects. On the one hand, it relates to differential preferences for specific courses of study related to the cultural orientations of the family of origin. On the other hand, it relates to the social networks made available to students over and above the networks they have available from their own family. As these social networks imply weak ties between the students (Granovetter 1993), this variable is situated at the school-course level rather than the level of course of study. In this way it represents both kinds of effects (through the course followed and through the school attended). Also at the school-course combination level, we include the unemployment rate in the region where the educational institution is located (CBS 2002). A total of 18 regions ('RBA-areas') are distinguished. This variable indicates the overall employment situation in the region where the school-leavers attended school. This variable is included to control for between-school variation that is due to regional rather than school-specific characteristics.

At the level of courses of study, we calculated the following characteristics. The first characteristic is level of education. Level of education is measured in years of schooling (see appendix A). The following values were assigned: short tracks MBO 12 years, long tracks MBO 14 years, HBO 17 years and WO 19 years. This characteristic is not only taken as an indicator of the accumulated human capital, but is also interpreted as indicator of the general learning abilities.

The second course characteristic refers to the selectivity of the course of study. Even within a given level of education, there is still considerable variation in the quality or level of the courses offered. To estimate this quality variation within given levels of education, we calculated for each course of study the percentage of students having the highest level of first-phase secondary education. Within each educational level these indicators were then standardized. This means that the measure can be compared across all educational levels (see appendix A). It gives a ranking of courses of study within each level of education: 
university level (WO), higher vocational education (HBO), and intermediate vocational education (MBO) long tracks and short tracks.

The third characteristic is the course specificity. This refers to the relative degree to which the course of study in question provides the required skills. The more specific a course of study prepares for a particular job, the less additional training their school-leavers need.

Table 1

Statistical description of the variables used in the analysis (maximally 21,272 school-leavers within maximally 992 schools within 220 courses of study)

\begin{tabular}{|c|c|c|c|}
\hline Variables & Percentage & Mean & Standard deviation \\
\hline \multicolumn{4}{|l|}{ Independent variables } \\
\hline \multicolumn{4}{|l|}{ Level 1 variables } \\
\hline Age $(18-34)$ & & 24.5 & 2.6 \\
\hline Female (versus male) & 54.8 & & \\
\hline Ethnic minority (versus Dutch) & 2.1 & & \\
\hline Preparatory education HAVO (versus VBO/MAVO) & 27.4 & & \\
\hline Preparatory education VWO (versus VBO/MAVO) & 35.7 & & \\
\hline Parental level of education (6-19) & & 12.0 & 3.0 \\
\hline Extrinsic work value $(1-5)$ & & 3.9 & 0.7 \\
\hline Intrinsic work value $(1-5)$ & & 4.3 & 0.5 \\
\hline Social work value $(1-5)$ & & 4.0 & 0.7 \\
\hline \multicolumn{4}{|l|}{ Level 2 variables } \\
\hline Regional unemployment rate $(3-8)$ & & 5.1 & 1.1 \\
\hline Mean parental level of education $(6-19)$ & & 11.9 & 1.4 \\
\hline \multicolumn{4}{|l|}{ Level 3 variables } \\
\hline Proportion of females $(0-1)$ & & 0.5 & 0.3 \\
\hline Specificity of education $(-17.9--1.2)$ & & -9.4 & 4.9 \\
\hline Selectivity of education $(-0.6-1.0)$ & & 0.0 & 0.2 \\
\hline Level of education $(12-19)$ & & 17.0 & 2.1 \\
\hline \multicolumn{4}{|l|}{ Dependent variables } \\
\hline Being unemployed (versus employed) & 2.7 & & \\
\hline Being temporary employed (versus permanent employed) & 15.3 & & \\
\hline Occupational prestige (15 - 86) & & 56.0 & 14.0 \\
\hline Log gross hourly wages $(0.0-6.1)$ & & 3.0 & 0.3 \\
\hline
\end{tabular}

Source: school-leaver surveys ROA 1998

From this it follows, that school-leavers from more general courses of study will require more on-the-job training in order to perform adequately on the work floor than those who have completed an occupation-specific course of study, provided that the latter end up working in a matching job. Specificity is based on the occupational opportunities on the labor market. If workers from a particular course of study are largely concentrated in one occupation, then this course of study is considered to be highly specific. If, on the other hand, workers from a particular course of study are dispersed across a great number of occupations, then this course of study is considered to be highly generic. The occupational opportunities are measured by calculating a Gini-Hirschman coefficient for the range of occupations for each 
course of study. The coefficient can take values between 0 (all workers are located in one occupation) and 100 (all workers are equally distributed across all possible occupations). A high value therefore represents low specificity. For the present analysis, we assigned such a coefficient to all courses of study. The coefficients were estimated using the Dutch Labor Force Surveys of 1995 and 1996. Since we are interested in the specificity of courses of study, the reverse sign of the coefficients is used, which means that a high value indicates a high degree of specificity. The range of this variable is between -17.9 and -1.2.

Finally, we included the proportion of female school-leavers in the course of study as a characteristic to distinguish courses with high proportions of women from courses with low proportions of women. It is a well-known fact that so-called female-dominated courses of study render much lower returns than male-dominates courses of study due to the lower appreciation of 'female' occupations on the labor market (Charles 1992).

A statistical description of the variables used in the empirical analysis is presented in Table 1.

\section{Results}

\section{Unemployment}

Table 2 displays the results of a logistic 3-level random intercept model analyzing the likelihood of being unemployed. Model 0 is the baseline model where only the intercept is estimated. The level one residual variance is fixed to 1 (cf. Snijders and Bosker 1999). Model 1 includes the individual characteristics and the control variable at the school level (i.e. the regional unemployment rate), in Model 2 the aggregate characteristics are added (average level of parental education and proportion female school-leavers) and in Model 3 the course characteristics are added.

The baseline model shows significant variation in the likelihood of being unemployed between courses of study and schools. As might be expected, the variation between courses of study is higher than the variation between schools, indicating that the course of study followed affects the likelihood of having a job much more than the specific school where the course of study was followed. As the level one variance is fixed at 1 , the residual variance components cannot directly be compared across the different models (see also section 2). We therefore look at the changes in the percentages rather than the changes in the variances it self. After introduction of the individual characteristics and the control variable at the school level in Model 1, almost 13 percent of the total variance can be explained. The decrease in residual variance at the individual level is 6 percent, which is the same as the decrease in residual variance at the level of courses of study. This implies that the modeled characteristics explain just as much variation within schools and courses of study as they explain variation between courses of study. The residual variance at the level of courses of study drops from 26 to 20 percent, which implies that some $24\left((1-19.7 / 26.0)^{*} 100\right)$ percent of the variance at this level is explained by modeled characteristics of the student population and the regional unemployment rate. The residual variance at the school level decreases slightly from 7.9 to 7.5 percent, indicating that not all between-school variation can be 
explained by differences in regional unemployment rates or the modeled individual characteristics. In model 2 the aggregated student characteristics are added to the model, implying a further drop in the residual variance at the level of courses of study from 19.7 to 14.6 percent. Adding the other course characteristics in model 3 leads to a further decrease to 13.3 percent. This implies that the modeled characteristics 'explain' some 50 percent of the original variation between courses of study.

The estimation results of Model 3 first of all show that older school-leavers tend to be more often hit by unemployment than younger school-leavers (even after controlling for years of schooling). In the following analyses we will see that age has, in general, a positive effect on the other socio-economic outcomes. We therefore interpret this effect as older schoolleavers having higher reservation wages. They do not accept the first job offer, but wait until they find an acceptable job ${ }^{1}$.

Being a female seems to have a negative effect on employment chances (compare model 1 ), but this effect disappears once we control for the proportion of female school-leavers in the course of study. Model 3 shows that having followed 'female-dominated' studies significantly increase the odds of becoming unemployed, whether you are a male or a female. A 10 percent point increase in the proportion of females in the course of study is associated with a 12 percent $\left(e^{0.1147}=1.12\right)$ increase in the odds of being unemployed. The employment chances for ethnic minorities are far worse than for natives: the odds of being unemployed are three times as high as the corresponding odds for natives.

In addition, the social background of school-leavers, as indicated by parental level of education, has a negative effect on employment chances: the higher the parental level of education, the larger the odds of being unemployed. This effect must be interpreted - just like the age effect - as indicating higher reservation wages for school-leavers coming from more privileged families. They expect a job to meet certain standards (high prestige, high income) and can afford themselves to wait for a proper job offer. This is in line with previous literature (Breen and Goldthorpe 1997) pointing out that people from higher social strata are less risk averse. This interpretation is confirmed by the fact that - as we shall see later - the (individual) effect of parental education on occupational prestige and income is positive. The odds of becoming unemployed are multiplied with 1.04 for each additional year of schooling of both parents. Apart from the individual effect, there is an additional effect of the aggregate parental level of education in the school-course combination. Having followed a course that is dominated by students from more privileged backgrounds increases the odds of becoming unemployed. This result is on first sight rather unexpected, the more so as this variable also has a negative effect on the other socio-economic outcomes. A closer look at the data learns that this effect is due to the lower labor market prospects of the cultural-oriented courses of study. These courses are mainly followed by students whose parents have a high

1. The other interpretation would be that differences in age are caused by deviations from the 'standard' school career (either because the school-leaver repeated class or because he or she left education for a while). This would cause a negative signal in the labor market. However, this interpretation is not supported by the results regarding the other socio-economic outcomes studied in this article, where age has a positive effect. 
educational level. Given the model specification, where we control for other characteristics such as level of education, this variable differentiates mainly between cultural-oriented courses and other courses.

Table 2

Results of logistic 3-level analysis of being unemployed: logit effects $(21,272$ school-leavers within 992 schools within 220 courses of study)

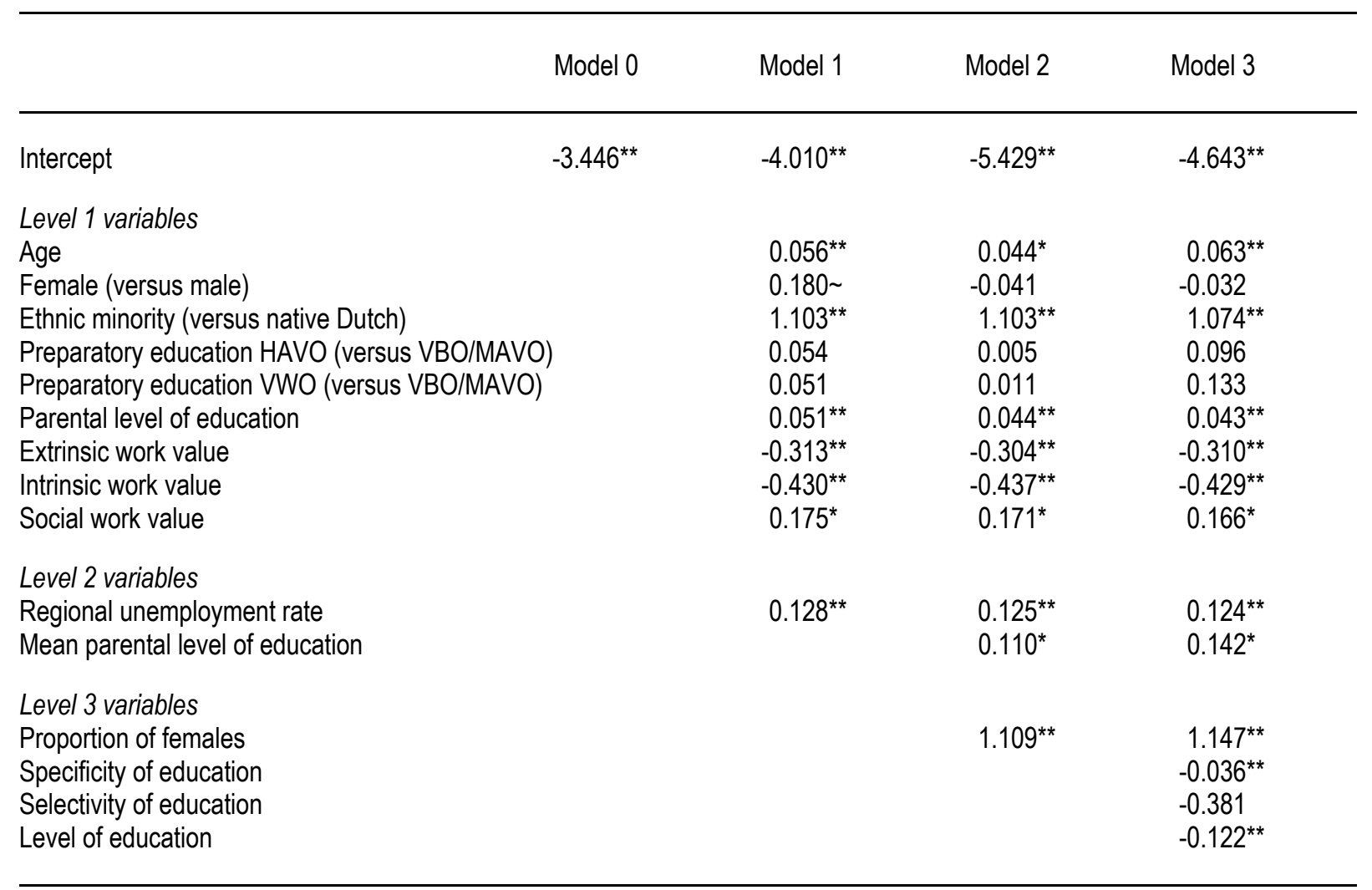

Variance components (percentages)

Residual variance level 1 :

school-leavers

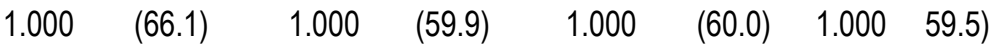

schools

Residual variance level 3:

$\begin{array}{lrlrlllll}0.120 \sim & (7.9) & 0.125 \sim & (7.5) & 0.106 & (6.4) & 0.133 \sim & (7.9) \\ & & & & & & & \\ 0.394^{* *} & (26.0) & 0.329^{* *} & (19.7) & 0.244^{* *} & (14.6) & 0.224^{* *}(13.3) \\ 0.000 & (0.0) & 0.216 & (12.9) & 0.316 & (19.0) & 0.325 & (19.3) \\ 1.514 & (100.0) & 1.670 & (100.0) & 1.666 & (100.0) & 1.682(100.0)\end{array}$

courses of study

Explained variance

$1.514 \quad(100.0)$

$1.670(100.0)$

$1.666(100.0) \quad 1.682(100.0)$

$\sim=p<0.10 ;{ }^{*}=p<0.05 ;{ }^{* *}=p<0.01$ (two tailed)

Source: school-leaver surveys ROA 1998

Work values are also important in predicting employment chances. School-leavers who have a low extrinsic or intrinsic work value are more often found unemployed than those with a high extrinsic or intrinsic work value. Both effects have the same sign, indicating that it is work motivation as such which affects the employment chances, be it extrinsic or intrinsic. On the other hand, school-leavers who stress social aspects like 'the possibility to combine work and family' or 'contacts with colleagues' as very important are most likely to be 
unemployed. This indicates that a strong social orientation in work values also indicates a lower labor market attachment.

The overall employment situation in the region where the school-leavers attended school affects their employment chances: each percent point increase in the regional unemployment rate increases the odds of becoming unemployed with 13 percent. Part of the differences between schools is therefore related to the fact that schools are located in areas that differ in employment prospects. Nonetheless, even controlling for these regional labor market differences, we still find significant (albeit small) differences between the schools, which may relate to characteristics of the quality of the school and the teaching staff not included in this model.

Introduction of the course characteristics in Model 3 adds only little to the explained variation. The residual variance at the course of study level decreases from 14.6 to 13.3 percent. Nevertheless, there are significant effects of the level of education and the specificity of the course of study. Each additional year of schooling decreases the odds of being unemployed with 11 percent. Specificity of the course also decreases the odds of being unemployed: apparently school-leavers from specific courses of study have a comparative advantage on the labor market as a result of their lower training costs. One point increase in specificity (on a scale ranging from -18 to -1 ) decreases the odds with 4 percent. We find no effects of the selectivity of the course of study followed on the employment chances.

\section{Temporary contract}

Table 3 displays the results with respect to the likelihood of having a temporary job rather than a permanent one for school-leavers who are employed. If we look the estimates of the variance components of the baseline model, we can conclude that again there are significant differences between courses of study and schools with respect to temporary employment. The variation between courses of study is about seven times as large as the variation between schools, indicating that the course of study followed is much more important in predicting the odds of having a temporary employment contract than the school which was attended.

Introduction of the individual level variables and the regional unemployment rate causes a drop in the residual variation between courses of study from 25.5 to 18.9 percent. Introduction of the aggregate characteristics in model 2 causes a further drop in the residual variation of some 4 percent to 14.8 percent. After introducing the remaining course characteristics in model 3 , the residual variance at the course of study level is 12.2 percent. This means that more than 50 percent of the original variation between courses of study is explained by the modeled characteristics. The variation between school-course combinations is less well explained by the modeled characteristics and decreases from 3.8 to 3.1 percent. 
Table 3

Results of logistic 3-level analysis of being temporary employed: logit effects $(19,922$ school-leavers within 983 schools within 220 courses of study)

\begin{tabular}{|c|c|c|c|c|c|c|c|c|}
\hline & \multicolumn{2}{|c|}{ Model 0} & \multicolumn{2}{|c|}{ Model 1} & \multicolumn{2}{|c|}{ Model 2} & \multicolumn{2}{|c|}{ Model 3} \\
\hline Intercept & $-1.641^{*}$ & & -0.028 & & -1.132 & & -1.074 & \\
\hline \multicolumn{9}{|l|}{ Level 1 variables } \\
\hline Age & & & -0.034 & & $-0.043^{\prime}$ & & -0.024 & \\
\hline Female (versus male) & & & $0.238^{\prime}$ & & $0.140^{\prime}$ & & 0.150 & \\
\hline Ethnic minority (versus native Dutch) & & & $0.488^{\prime}$ & & $0.492^{\prime}$ & & $0.470^{\prime}$ & \\
\hline Preparatory education HAVO (versus VBO/MAV & & & -0.010 & & -0.042 & & 0.025 & \\
\hline Preparatory education VWO (versus VBO/MAVC & & & $-0.228^{\prime}$ & & $-0.265^{\prime}$ & & -0.158 & \\
\hline Parental level of education & & & 0.018 & & $0.017^{\prime}$ & & 0.016 & \\
\hline Extrinsic work value & & & -0.324 & & $-0.320^{\circ}$ & & -0.332 & \\
\hline Intrinsic work value & & & $-0.092^{\prime}$ & & -0.095 & & -0.094 & \\
\hline Social work value & & & 0.076 & & $0.075^{\prime}$ & & 0.069 & \\
\hline \multicolumn{9}{|l|}{ Level 2 variables } \\
\hline Regional unemployment rate & & & $0.052^{\prime}$ & & $0.048^{\prime}$ & & 0.044 & \\
\hline Mean parental level of education & & & & & 0.076 & & 0.331 & \\
\hline \multicolumn{9}{|l|}{ Level 3 variables } \\
\hline Proportion of females & & & & & 0.948 & & 0.811 & \\
\hline Specificity of education & & & & & & & -0.003 & \\
\hline Selectivity of education & & & & & & & -0.153 & \\
\hline Level of education & & & & & & & -0.215 & \\
\hline \multicolumn{9}{|l|}{ Variance components (percentages) } \\
\hline $\begin{array}{l}\text { Residual variance level 1: } \\
\text { school-leavers }\end{array}$ & 1.000 & (70.8) & 1.000 & $(70.6)$ & 1.000 & $(67.5)$ & 1000 & (66 7) \\
\hline Residual variance level 2: schools & $0.053^{* *}$ & $(3.8)$ & $0.049^{* *}$ & $(3.5)$ & $0.042^{*}$ & $(2.8)$ & $0.047^{\star}$ & (3.1) \\
\hline Residual variance level 3: & & & & & & & & \\
\hline courses of study & $0.360^{* *}$ & (25.5) & $0.268^{* *}$ & (18.9) & $0.219^{* *}$ & (14.8) & $0.183^{* *}$ & $(12.2)$ \\
\hline Explained variance & 0.000 & $(0.0)$ & 0.099 & $(7.0)$ & 0.220 & (14.9) & 0.270 & (18.0) \\
\hline Total variance & 1.413 & $(100.0)$ & 1.416 & $(100.0)$ & 1.481 & $(100.0)$ & 1.500 & (100.0) \\
\hline
\end{tabular}

$\sim=p<0.10 ;{ }^{*}=p<0.05 ;{ }^{* *}=p<0.01$ (two tailed)

Source: school-leaver surveys ROA 1998

Age affects the likelihood of being temporary employed. Each year increase in age (controlled for the level of education) reduces the odds of having a temporary job with 2 percent (see model 3). Female school-leavers are more often employed on a temporary basis than their male counterparts. The implied odds ratio is 1.16. Moreover, having followed a female-dominated course of study also increases the odds of getting a temporary job. A 10 percent point increase in the proportion of female school-leavers is associated with an 8 percent increase in the odds. Again this supports the weaker position of females and especially of school-leavers from female-dominated courses on the labor market. The same applies for ethnic minorities. Compared to natives, their odds of being temporary employed are 60 percent higher. The level of preparatory education affects the likelihood of having a temporary job as well, even after controlling for the level of education obtained. Model 3 
shows that having followed the highest track in preparatory education decreases the odds of having a temporary job with 15 percent.

The social background of school-leavers has the same effect as in the analysis with respect to unemployment. There is a strong effect of the aggregate characteristics, indicating that school-leavers from cultural-oriented courses have on average higher chances of getting a temporary job. There is also an individual effect of family background: the higher the parental level of education is, the larger the probability of having a temporary job. For each additional year of schooling of the parents, the odds increase with 2 percent. Again, the effect might be explained by the fact that school-leavers with higher educated parent can 'afford' themselves to accept temporary jobs, because they have more resources to fall back to once they get unemployed. Besides, temporary jobs may also be an important investment for the future career. Jobs that require a large amount of additional training after initial education, like the jobs that are offered in the apprenticeship system, or the jobs that are open for medical students, are almost always on a temporary basis. However, these jobs may have good long-term perspectives. This 'investment' aspect of temporary jobs is reflected in the fact that intrinsic work values do not have the same profound effect as in the previous analysis. School-leavers who value intrinsic job characteristics like 'creativity' or 'challenge' have a lower probability of working in a temporary job, but the effect is much smaller than in the analysis with respect to unemployment. On the other hand, having a strong extrinsic orientation towards work values decreases the likelihood of having a temporary job much stronger. If one values 'high income' and 'job security' very strongly, this affects the job search strategy and ultimately the odds of being successful in finding a permanent job. The opposite is found for social work values. Stressing items like 'contacts with colleagues' and 'possibility to combine work and family' is linked with a lower labor market attachment. School-leavers who stress these items very strongly find themselves more often in temporary positions (although the effect is not as strong as in the analysis of unemployment).

Labor market entrants who left school in regions characterized by a high unemployment rate have a larger probability of being temporary employed: each percent point increase in the regional unemployment level is associated with a 4 percent increase in the odds. However, the variation between schools is not much changed by introducing this variable, leaving most of the school effects unexplained.

Introduction of the remaining course characteristics in Model 3 explains only a minor part of the differences between courses of study as found in Model 2. Of the course characteristics, only the level of education has a significant effect on the likelihood of being temporary employed. Each additional year of schooling decreases the odds with 19 percent.

\section{Occupational prestige}

Table 4 displays the results with respect to the occupational prestige of the job. Differences in occupational prestige are primarily related to the course of study followed. About two thirds of the total variation in prestige scores is related to the course of study and only one 
third relates to individual differences within courses of study between school-leavers. The attended school does not play any role at all in the distribution of occupational prestige among school-leavers: only 1 percent of the total variation in occupational prestige scores relates to the school where the educational qualification was obtained. Still the betweenschool variation is significantly different from zero, implying that the school has a rather small effect on later occupational prestige.

\section{Table 4}

Results of 3-level analysis of occupational prestige: unstandardized regression coefficients $(20,533$ school-leavers within 989 schools within 220 courses of study)

\begin{tabular}{|c|c|c|c|c|c|c|c|c|}
\hline & \multicolumn{2}{|c|}{ Model 0} & \multicolumn{2}{|c|}{ Model 1} & \multicolumn{4}{|c|}{ Model 3} \\
\hline Intercept & 56.81 & & $49.080^{*}$ & & -8.656 & & $-19.420^{*}$ & \\
\hline \multicolumn{9}{|l|}{ Level 1 variables } \\
\hline Age & & & $0.122^{*}$ & & $0.114^{*}$ & & $0.089^{*}$ & \\
\hline Female (versus male) & & & $-0.691^{*}$ & & $-0.663^{*}$ & & $-0.659^{*}$ & \\
\hline Ethnic minority (versus native Dutch) & & & -0.101 & & -0.087 & & -0.019 & \\
\hline Preparatory education HAVO (versus VBO/A & MAVO) & & $0.610^{*}$ & & $0.592^{*}$ & & $0.514^{*}$ & \\
\hline Preparatory education VWO (versus VBO/M & AVO) & & $0.756^{*}$ & & $0.708^{*}$ & & $0.557^{*}$ & \\
\hline Parental level of education & & & $0.075^{*}$ & & $0.071^{*}$ & & $0.073^{*}$ & \\
\hline Extrinsic work value & & & 0.044 & & 0.055 & & 0.074 & \\
\hline Intrinsic work value & & & $0.695^{*}$ & & $0.683^{*}$ & & $0.667^{*}$ & \\
\hline Social work value & & & 0.031 & & 0.032 & & 0.031 & \\
\hline \multicolumn{9}{|l|}{ Level 2 variables } \\
\hline Regional unemployment rate & & & 0.070 & & 0.077 & & 0.096 & \\
\hline Mean parental level of education & & & & & $5.215^{\star}$ & & $-1.274^{*}$ & \\
\hline \multicolumn{9}{|l|}{ Level 3 variables } \\
\hline Proportion of females & & & & & $-12.460^{*}$ & & $-8.968^{\star}$ & \\
\hline Specificity of education & & & & & & & $0.114-$ & \\
\hline Selectivity of education & & & & & & & $5.345^{\star}$ & \\
\hline Level of education & & & & & & & $5.335^{\star}$ & \\
\hline \multicolumn{9}{|l|}{ Variance components (percentages) } \\
\hline Residual variance level 1: school-leavers & $73.160^{* *}$ & $(33.9)$ & $72.900^{* *}$ & $(33.7)$ & $72.900^{\star *}$ & $(33.7)$ & $72.820^{\star *}$ & $(33.7)$ \\
\hline Residual variance level 2: schools & $1.096^{* *}$ & $(0.5)$ & $1.062^{* *}$ & $(0.5)$ & $1.063^{\star *}$ & $(0.5)$ & $1.063^{\star *}$ & $(0.5)$ \\
\hline Residual variance level 3 : courses of study & $141.800^{* *}$ & $(65.6)$ & $131.400^{* *}$ & $(60.8)$ & $89.310^{\star *}$ & $(41.3)$ & $28.780^{\star *}$ & $(13.3)$ \\
\hline Explained variance & 0.000 & $(0.0)$ & 10.694 & (4.9) & 52.783 & $(24.4)$ & 113.393 & $(52.5)$ \\
\hline Total variance & 216.056 & $(100.0)$ & 216.056 & $(100.0)$ & 216.056 & $(100.0)$ & 216.056 & $(100.0)$ \\
\hline
\end{tabular}

$\sim=p<0.10 ;{ }^{*}=p<0.05 ;{ }^{* *}=p<0.01$ (two tailed)

Source: school-leaver surveys ROA 1998 
Introduction of the individual level variables and regional unemployment rate explains only a part of the variation between courses of study. The residual variance at the course level drops from 65.5 to 60.8 percent of the total variation. Note also that the variance component at the individual level is hardly affected by the individual characteristics included in the model. This means that the variation within courses of study and schools between schoolleavers is largely left unexplained. Introducing the aggregate characteristics causes a drop in the between-courses variation from 60.8 to 41.3 percent. The inclusion of the other course characteristics in model 3 explains almost all of the remaining variation at the level of courses of study, leaving only 13.3 percent unexplained.

The age of school-leavers has a positive effect on the occupational prestige. Controlled for the course characteristics in Model 3, each additional year in age yields a small increase in occupational prestige of 0.1 point on a scale ranging from 13 to 87 . Gender has both an individual effect and an aggregate effect. School-leavers (males and females) from femaledominated courses end up in jobs with considerable less occupational prestige than schoolleavers from male-dominated courses. A 10 percent point increase in the proportion of female school-leavers is associated with a decrease of occupational prestige of 0.9 points. At the individual level (i.e. within courses), women also find themselves in jobs with lower occupational prestige. Being female is associated with a 0.7 point lower prestige score. We find no effect of belonging to an ethnic minority group. This indicates that the problems that minorities face concentrate on getting a job as such: they have more difficulties to find a job, but the kinds of jobs they get are not different from those of the native school-leavers. This may be caused by differences in job search behavior or lack of adequate labor market information on the part of school-leavers from ethnic minority groups, but it may also still relate to discriminatory behavior on the part of the employers, preventing ethnic minorities to enter the prestigious jobs. The level of preparatory education also affects the occupational prestige, even if one controls for the level of education that was ultimately attained. Having attended one of the two highest tracks in secondary education (HAVO or VWO) yields an increase of the occupational prestige of 0.5 points. The social background of school-leavers provides significant resources to find jobs of a high occupational prestige. For each year of additional schooling of the parents, the occupational prestige of their offspring is increased with 0.07 points. This holds for the individual effect within each course of study and within schools. On the aggregate level, however, parental level of education has a negative effect, again pointing to bad labor market prospects of cultural-oriented courses. Finally, intrinsic work values play a role. School-leavers who stress work values like 'challenge' and 'creativity' find themselves in jobs with a higher occupational prestige. One standard deviation increase in the intrinsic work value yields an increase of the occupational prestige of 0.7 points. There is no significant effect of the regional unemployment rate on the occupational prestige.

As pointed out before, the occupational prestige attained is predominantly affected by the course of study that has been followed. As could be expected, the level of schooling has a profound effect on the occupational prestige. Each year of schooling yields an increase of the occupational prestige of 5.3 points. But even within different levels of education there is 
considerable variation between courses of study in the average attained prestige level. These differences are strongly related with the selectivity of the course of study, indicated by the percentage of students in this course who attained the highest track in preparatory secondary education. Note that this has an effect over and above the individual effect of preparatory education discussed earlier. Stated differently, following the highest track in secondary education works in two ways. One is a direct individual effect: within the same course of study school-leavers with a higher level of preparatory education attain a higher occupational prestige. The other effect relates to the student composition of the different courses of study. Within the same level of education, school-leavers from highly selective courses of study obtain a higher occupational prestige. The aggregate effect is much stronger than the individual effect. One standard deviation increase in the selectivity yields an increase of 5.3 prestige points. As noted earlier, the individual effect of the dummies for preparatory education show returns of only 0.5 prestige points. Specificity of the course also has a small effect on the prestige scores obtained: school-leavers from more specific oriented courses reach on average a higher prestige level than school-leavers from more generic courses. One point increase in specificity (on a scale from -18 to -1 ) yields an increase in prestige of 0.1 point.

\section{Income}

Table 5 gives the results of the analysis with the log gross hourly wages as the dependent variable. As occupational prestige and income are fairly high correlated ( $r=0.47)$, it is not surprising that this analysis gives more or less the same picture as the previous one. However, there are also some interesting differences. Striking, for example, is the fact that income is much more affected by individual differences than occupational prestige. From the total variation in income in the baseline model 56 percent is attributed to differences between school-leavers and 43 percent to differences between courses of study. In the analysis regarding occupational prestige these figures were 34 and 66 percent respectively. Just like the analysis with respect to occupational prestige, the analysis regarding wages shows only very small effects of schools. Only 1 percent of the total variation in wages can be attributed to the school attended. Still this school effect is significantly deviating from zero. An important part of the variation between courses of study is caused by differential selection of students.

Introduction of the individual level variables and the regional unemployment rate causes a large drop in the residual variance between courses of study from 43 to 25 percent. In other words, a significant part of the variation between courses of study is caused by the composition of the student population: some courses of study attract students with favorable characteristics. The interesting thing is that these student characteristics affect all students of the courses of study rather than the individuals themselves. At the individual level, the variation is hardly affected. This indicates that most of the individual differences in wages within courses of study are not related to any of the variables included in the model. 
Table 5

Results of 3-level analysis of log gross hourly wages: unstandardized regression coefficients $(18,781$ school-leavers within 977 schools within 220 courses of study)

\begin{tabular}{|c|c|c|c|}
\hline Model 0 & Model 1 & Model 2 & Model 3 \\
\hline Intercept & $2.265^{\star *}$ & $1.403^{* *}$ & $1.238^{* *}$ \\
\hline \multicolumn{4}{|l|}{ Level 1 variables } \\
\hline Age & $0.027^{* *}$ & $0.026^{* *}$ & $0.025^{* *}$ \\
\hline Female (versus male) & $-0.028^{* *}$ & $-0.027^{\star *}$ & $-0.027^{* *}$ \\
\hline Ethnic minority (versus native Dutch) & -0.008 & -0.007 & -0.005 \\
\hline Preparatory education HAVO (versus VBO/MAVO) & $0.034^{* *}$ & $0.032^{* *}$ & $0.029^{* *}$ \\
\hline Preparatory education VWO (versus VBO/MAVO) & $0.035^{\star *}$ & $0.031^{* *}$ & $0.024^{* *}$ \\
\hline Parental level of education & $0.002^{*}$ & $0.001 \sim$ & $0.001^{*}$ \\
\hline Extrinsic work value & $0.012^{* *}$ & $0.013^{* *}$ & $0.014^{* *}$ \\
\hline Intrinsic work value & $0.021^{* *}$ & $0.020^{* *}$ & $0.020^{* *}$ \\
\hline Social work value & $-0.012^{* *}$ & $-0.012^{* *}$ & $-0.012^{* *}$ \\
\hline \multicolumn{4}{|l|}{ Level 2 variables } \\
\hline Regional unemployment rate & $-0.006^{\star *}$ & $-0.006^{*}$ & $-0.005^{*}$ \\
\hline Mean parental level of education & & $0.077^{* *}$ & 0.002 \\
\hline \multicolumn{4}{|l|}{ Level 3 variables } \\
\hline Proportion of females & & $-0.137^{\star *}$ & $-0.104^{* *}$ \\
\hline Specificity of education & & & $0.003^{*}$ \\
\hline Selectivity of education & & & 0.028 \\
\hline Level of education & & & $0.066^{* *}$ \\
\hline
\end{tabular}

Variance components (percentages)

Residual variance level 1: school-leavers $\quad \begin{array}{llllllll}0.071^{* *} & (56.3) & 0.069^{* *} & (54.8) & 0.069^{* *} & (54.8) & 0.069^{* *} & (54.8)\end{array}$

Residual variance level 2: schools

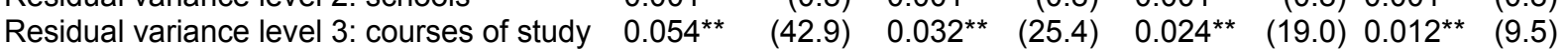

$\begin{array}{llllllllll}\text { Explained variance } & 0.000 & (0.0) & 0.024 & (19.0) & 0.032 & \text { (25.4) } & 0.044 & \text { (34.9) }\end{array}$

$\begin{array}{lllllllll}\text { Total variance } & 0.126 & (100.0) & 0.126 & (100.0) & 0.126 & \text { (100.0) } & 0.126 & (100.0)\end{array}$

$\sim=p<0.10 ;{ }^{*}=p<0.05 ;{ }^{* *}=p<0.01$ (two tailed)

Source: school-leaver surveys ROA 1998

Introduction of the aggregate student characteristics in Model 2 causes a drop in the residual variation between courses of study from 25.4 to 19 percent. The remaining course characteristics explain most of the remaining variation, leaving only 9.5 percent of the variation unexplained at the level of courses of study. Again, we can note a remarkable difference with the analysis concerning occupational prestige. The corresponding figures for the models in the analysis on occupational prestige were $60.8,41.3$ and 13.3 percent respectively. In other words, the variation between courses of study in occupational prestige can almost entirely be explained by differences in course characteristics, like the level and the selectivity of the course of study obtained. In the case of wages, however, the variation between courses of study must also to a large degree be attributed to differential selection of students into these courses of study. Both characteristics of the student composition and the course of study attended determine the differences in wages. Note, however, that the same individual characteristics do not explain differences within courses of study. 
Age has a positive effect on wages and this effect is not altered by the introduction of the course characteristics. Each additional year in age yields a wage increase of 2.5 percent. Since all respondents left school one year and a half before the survey took place, the age effect is not related to differences in working experience of school-leavers after they left education. Although the age effect may partly pick up differences in working experience before or during education, the main explanation for the age effect is that school-leavers are differentially confronted with minimum wages. For young people between 16 and 21 years of age, minimum wages in the Netherlands rise sharply with age. Within each course of study, women earn about 3 percent less than men. The aggregate gender effect is even stronger. Both males and females from female-dominated courses earn less: a 10 percent point increase in the proportion of female school-leavers is associated with a decrease in the earnings of $1 \%$. These gender differences are in line with the lower occupational prestige scores for women and school-leavers from female-dominated courses. Together with the effects of gender on unemployment and temporary employment, we can conclude that female school-leavers and especially school-leavers from female-dominated courses of study face worse labor market prospects than either male school-leavers or school-leavers from male-dominated courses of study. As in the analysis with respect to occupational prestige, coming from an ethnic minority background has no negative effects on the wages. School-leavers, who followed one of the two highest tracks in the first phase of secondary education before entering further education, have a wage premium of some 3 percent, even after controlling for the level of education of their final course of study. The social background of school-leavers also has a small, but significant effect on their wages. For each additional year of schooling of the parents, the gross hourly wages of their offspring is increased with 0.2 percent. We find no effect of the aggregate parental level of education, indicating that cultural-oriented studies do not pay worse than other courses of study. Furthermore, both intrinsic and extrinsic work values increase the hourly wages, but intrinsic work values pay off more than extrinsic work values do. Apparently, stressing items like 'high income' gives a wage premium, but this premium is not as large as the wage premium for intrinsic work values like 'challenge' and 'creativity'.

The effect of the regional unemployment rate shows an interesting difference with the previous analysis on occupational prestige. Regional differences in labor market opportunities do not affect the occupational prestige obtained, but they have a small effect on the wages earned. Each percent point increase in the regional unemployment rate is associated with a decrease in the wages of school-leavers of 0.5 percent.

The most profound effect on wages comes from the level of education. Each year of schooling increases the wages of the school-leavers with some 7 percent. If we compare this with the wage effect of parental education, we can clearly calculate the difference in impact. The years of schooling of the school-leaver count more than 60 times as much as the years of schooling of the parents. It is interesting to note that - unlike the previous analysis on occupational prestige - the selectivity of courses of study has no impact on the initial wages. This might be caused by the fact that many jobs with a high occupational prestige - like physician, researcher - start with traineeships that offer relatively low pay in the beginning of 
the career. Specificity of the course of study does have an effect on the wages. On a scale from -18 to -1 one-point increase in specificity yields a wage premium of 0.3 percent.

\section{Conclusions}

Sociologists and economists have always regarded education as one of the most significant factors affecting socio-economic outcomes. In that respect, it is surprising to note that the total effect of education has not been assessed in previous research. What has been demonstrated is that specific aspects of education (e.g. the level of education or the reputation of the college) affect the socio-economic outcomes. The step forward in this article is that we give an indication of the total (measured and unmeasured) effect of education on different socio-economic outcomes. For that purpose, we used a multi level approach which enabled us to give an assessment of the total effect of education and to decompose this effect into the three sources of variation: differences between courses of study (affecting what is being taught), differences between teaching environments (affecting how things are taught) and differences in student population (affecting who is being taught).

It is clear that education has a large effect on socio-economic outcomes, but the impact varies widely between the different outcome indicators. If we define the effect of education as the combined effect of the course of study followed and the school attended, then the distribution of occupational prestige is to a large extent determined by education. Two thirds of the variation in occupational prestige is related with education. For income, the effect of education is some 44 percent. Put differently, social rewards in terms of prestige and status are more determined by education than economic rewards like earnings. This confirms the results found earlier by Kerckhoff et al. (2001). They found that educational attainment contributes more to the explanation of occupational status than to the explanation of earnings. In the case of employment chances and job security, the impact of education is about one third of the total variation. Although the latter two estimates of the effects of education might be a bit underestimated due to the binary character of the dependent variables, it seems clear that education has more profound effects on occupational prestige and wages than on employment chances and job security.

The analysis shows that the usual regression models typically underestimate the effects of education. The total effects of education on socio-economic outcomes go well beyond the effects that are usually measured with years of schooling. Again, this varies between the different labor market indicators. In our models for income and occupational prestige, some 20-25 percent of the total effect of education was left unexplained, while for employment chances the unexplained variance of education was 50-60 percent. In other words, if we had only looked at the measured characteristics of education, then we would have underestimated the total effect of education with $20-25$ and 50-60 percent respectively.

As explained above, the total effect of education may be attributed to three sources of variation. Schools do not seem to have a large impact, at least in the Netherlands. The differences between schools explain only 1 percent of the variation in occupational prestige 
and gross hourly wages. For employment chances and the odds of getting a temporary job, the impact of schools is a little bit larger. However, these school effects may relate to regional differences in job opportunities rather than differences in school quality. The small effect of schools is in line with the largely standardized educational system in the Netherlands, where differences in school quality are generally speaking rather small (De Graaf and Ultee 1998). Nevertheless, we find significant differences between schools for all labor market indicators, even after controlling for regional differences in general unemployment rates.

A significant part of the effect of education stems from differential selection of students into courses of study. In the case of wages, 40 percent of the original wage differences between schools and courses of study are 'explained' by modeled individual characteristics of the student composition and the regional unemployment rate, while 36 percent is explained by aggregate characteristics and course characteristics in the model. The remaining variation at the school and course of study level was left unexplained. For the employment chances and the chances of ending up in a temporary job, we find that around 20-25 percent of the variation between schools and between courses of study can be attributed to differences in student composition and regional unemployment rate, again some 20-25 percent to the aggregated student characteristics and the modeled course characteristics, while the remaining 50-60 percent was left unexplained. In the case of occupational prestige, the situation is quite different. Here, individual characteristics of the student population and regional unemployment rate explain only 7 percent of the original variation between schools and courses of study, while almost three quarters of the variation is explained by the aggregated student characteristics and course characteristics in the model. So again, we can notice a difference between social and economic rewards. The education effects of the latter are primarily explained by differential selection of students into courses of study. In the case of prestige, the differences between (schools and) courses of study are only partly related to differences in student composition and most of the differences are explained by characteristics of the course of study.

We used five school and course related characteristics to explain the effect of education. Two of these characteristics were aggregate student characteristics: the proportion of female school-leavers in the course of study and the average level of parental education of the students in the specific school-course combination. Female-dominated courses of study turned out to be associated with bad labor market prospects: high unemployment rates, high chances of ending up in temporary jobs, or jobs with a lower occupational prestige and lower earnings. These aggregated effects of gender exceeded the corresponding effects of gender within courses of study. The average level of parental education had a negative effect on most socio-economic outcomes (except wages). This - at first sight unexpected - negative effect is explained by the fact that students whose parents have a high level of education tend to be over-represented in cultural-oriented courses that usually are associated with bad labor market prospects. Given the model specification with controls for level of education, this variable thus differentiates between cultural-oriented courses and other courses. 
Next to this, three other course characteristics have been analyzed: the level of education, the selectivity of the course of study and the specificity of the course of study. Level of education turned out to have the most profound effects: each additional year of schooling decreases the odds of becoming unemployed, of getting a temporary job, and increased the occupational prestige and the earnings. In a way, these results simply echo former analyses on the outcomes of education. The effects of selectivity and specificity, however, are rather new. Having followed a course of study that is highly selective on entry level has profound effects on the occupational prestige of the job. As we also controlled for the entry level of education on the individual level, this selectivity effect is a course effect rather than an individual effect. In other words, highly selective courses of study have a positive effect on the social rewards for all students, regardless of their own entry level. This points to a screening effect, where employers use the information on the average entry level of education rather than the individual entry level of education to screen and select job applicants for high prestige jobs. The specificity of the course also affects the labor market outcomes. School-leavers from specific courses have a lower chance of becoming unemployed and hold jobs that have on average a higher prestige and higher earnings.

\section{References}

Becker, G. (1964). Human Capital. A Theoretical and Empirical Analysis, with Special Reference to Education. New York: NBER.

Bills, D. (2003). Credentials, Signals and Screens: Explaining the Relationship between Schooling and Job Assignment. Review of Educational Research, 73, 441-470.

Blau, P., and Duncan, O. (1967). The American Occupational Structure. New York: John Wiley \& Sons.

Breen, R., and Goldthorpe, J. (1997). Explaining Educational Differentials. Towards a Formal Rational Action Theory, Rationality and Society, 3, 275-305.

Bryck, A.S. and Raudenbush, S.W. (1992). Hierarchical Linear Models. Newbury Park: Sage.

CBS (2002). Beroepsbevolking; Naar Regio Vanaf 1991. Found at http://statline.cbs.nl on 2002-0116, Voorburg/Heerlen: Centraal Bureau voor de Statistiek.

Charles, M. (1992), Cross-National Variations in Occupational Sex Segregation, American Sociological Review, 57, 483-502.

Collins, R. (1979) The Credential Society: An Historical Sociology of Education and Stratification. New York: Academic Press.

Dolton, P. and Vignoles, A. (2000). The Effects of School Quality on Pupil Outcomes: An Overview. In: H. Heijke and J. Muijsken (eds.), Education, Training and Employment in the Knowledge Based Society (pp. 91-116). Houndmills: Palgrave Macmillan.

Goldstein, H. (1995). Multilevel Statistical Models. London: Edward Arnold.

Graaf, P. de and Ultee, W. (1998). Education and Early Occupations in The Netherlands Around 1990: Categorical and Continuous Scales and the Details of a Relationship. In: Y. Shavit and W. Müller (eds.), From School to Work. A Comparative Study of Educational Qualifications and Occupational Destinations (pp. 337-368). Oxford: Clarendon Press.

Granovetter, M. (1993), The Strength of Weak Ties, American Jourmal of Sociology, 78, 1360-1380.

Kalmijn, M. and Lippe, T. van der (1997). Type of Schooling and Sex Differences in Earnings in the Netherlands. European Sociological Review, 13, 1-15. 
Kerckhoff, A., Raudenbush, S. and Glennie, E. (2001). Education, Cognitive Skills and Labor Force Outcomes. Sociology of Education, 74, 1-24.

Müller, W., Luttinger, P., König, W. and Karle, W. (1989). Class and Education in Industrial Nations. International Journal of Sociology, 19, 3-39.

Mülller, W. and Gangl, M. (2003) (eds.). Transitions from Education to Work in Europe. The Integration of Youth into EU Labour Markets. Oxford: Oxford University Press.

Pallas, A. (2000). The Effects of Schooling on Individual Lives. In: M.T. Hallinan (ed.), Handbook of the Sociology of Education (pp. 499-525). New York: Kluwer Academic/Plenum Publishers.

Rosenbaum, J.E., T. Kariya, R. Settersten, T. Maier (1990), Market and network theories of the transition from high school to work. Their application to industrialized societies, Annual Review of Sociology, 16, pp. 263-299.

Rosenbaum, J.E. and Kariya, T. (1991), Do School Achievements Affect the Early Jobs of High School Graduates in the United States and Japan?, Sociology of Education, 64, 78-95.

Rosenbaum, J., DeLuca, S., Miller, S. and Roy, K. (1999). Pathways to Work: Short- and Long-term Effects of Personal and Institutional Ties. Sociology of Education, 72, 179-196.

Ryan, P. (2001). The School-to-Work Transition: A Cross-National Perspective. Journal of Economic Literature, 39, 34-92.

Shavit, Y. and Müller, W. (1998) (eds.). From School to Work. A Comparative Study of Educational Qualifications and Occupational Destinations. Oxford: Clarendon Press.

Schultz, T. (1961). Investment in Human Capital. American Economic Review, 51, 1-17.

Sixma, H. and Ultee, W. (1984). An Occupational Prestige Scale for the Netherlands in the Eigthies. In: B. Bakker, J. Dronkers and H. Ganzeboom (eds.), Social Stratification and Mobility in the Netherlands (pp.29-39). Amsterdam: SISWO.

Snijders, T., and Bosker, R. (1999). Multilevel Analysis. An Introduction to Basic and Advanced Multilevel Modeling. London/Thousand Oaks/New Delhi: Sage.

Spence, M. (1973). Job Market Signalling. Quarterly Journal of Economics, 87, 355-374.

Thurow, L. (1975). Generating Inequality. Mechanisms of Distribution in the U.S. Economy. New York: Basic Books.

Velden, R. van der and Smoorenburg, M. van (1999). Overscholing en Beloning: Het Effect van Verschillende Meetmethoden. Tijdschrift voor Arbeidsvraagstukken, 15, 111-123.

Werfhorst, H. van de and Kraaykamp, G. (2001). Four Field-Related Educational Resources and Their Impact on Labor, Consumption, and Sociopoliticial Orientation. Sociology of Education,74, 296-317.

Wilson, K. and Smyth-Lovin, L. (1983). Scaling the Prestige, Authority, and Income Potential of College Curricula. Social Science Research, 12, 159-186.

Wilson, K. (2002). The Effects of School Quality on Income. Economics of Education Review, 21, 579-588. 


\section{Appendix A}

\section{Construction of the level of education and selectivity of education}

Like most other European countries, in the Netherlands a distinction is made between general and vocational education. As shown in the diagram below, vocational education takes place at three educational levels in the Dutch education system: the level of lower vocational education (VBO), the level of intermediate vocational education (MBO) and the level of higher education (vocational colleges (HBO) and university (WO).

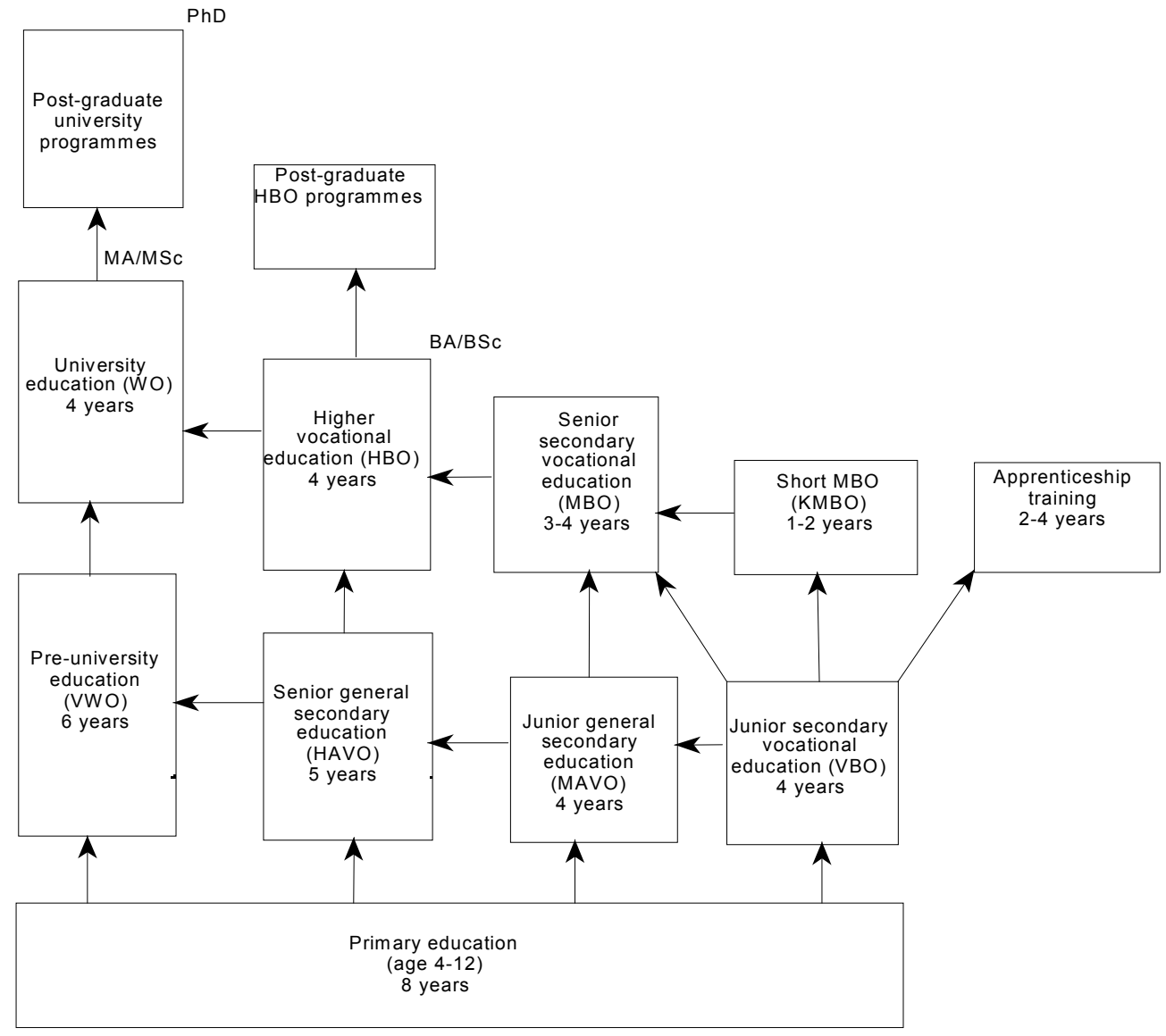

For the construction of the level of education, we used the scale developed by Van der Velden and Van Smoorenburg (1999). The rationale behind this scale is that it measures the cumulative number of years to reach the top of the education system taking the vocational route. The general tracks in secondary education are calculated by counting back from the level of the typical form of further education. In doing so, the duration of the different tracks in secondary education are weighted by their level. The assigned scores are: primary education 6 years (the first two years are not counted); VBO 10 years, KMBO 12 years, MBO 14 years, HBO 17 years, WO 19 years for the vocational tracks and MAVO 11 years, HAVO 13 years, VWO 15 years for the general tracks. The educational level of the parents 
is calculated as the average level of schooling of the father and the mother. In the case of a missing value of one of the parents, the level of schooling is equal to the level of schooling of the other parent.

The construction of the selectivity index was done as follows. For university education (WO), we calculated for each course of study the percentage of graduates that had pre-university education (VWO) as the highest form of preparatory education. Subsequently, this percentage was converted into a z-score for the courses of study at the university level. A high z-score implies a highly selective course of study, which means that relatively few students entered this course of study with, for example, higher vocational education (HBO) or a different preparatory education. For the courses of study in HBO, we also used the percentage of graduates with VWO as preparatory education as our measure for selectivity. Again, this percentage was first transformed into a z-score for all courses of study in HBO. In the case of the long tracks in intermediate vocational education (MBO), we looked at the percentage of school-leavers whose preparatory education was higher general secondary education (HAVO). For the courses of study at the level of short intermediate vocational education (KMBO), we took the percentage of those with HAVO or lower general secondary education (MAVO). Again, these scores were converted into z-scores for courses of study in the short tracks and the long tracks separately. Having thus calculated z-scores for the courses of study within each of the four educational levels, we standardized these scores again across all educational levels. The final z-scores vary from -0.6 to 1.0 . 